\title{
Effect of acute stressors, adrenocorticotropic hormone administration, and cortisol release on milk yield, the expression of key genes, proliferation, and apoptosis in goat mammary epithelial cells
}

\author{
G. F. Bomfim, G. K. F. Merighe, S. A. de Oliveira, and J. A. Negrao ${ }^{1}$ \\ Department of Basic Sciences, Faculty of Animal Science and Food Engineering, University of São Paulo, Pirassununga, São Paulo, Brazil, \\ $13635-900$
}

\begin{abstract}
Cortisol is essential to milk synthesis; however, different acute stressors and the exogenous administration of adrenocorticotropic hormone (ACTH) decrease milk yield. Therefore, the effect of cortisol on milk yield and its influence on the survival of mammary epithelial cells have not been fully elucidated. In this context, the objective of this study was to evaluate the effect of cortisol on the expression of growth hormone receptor $(G H R)$, insulin-like growth factor type 1 (IGF1), insulin-like growth factor type 1 receptor $(I G F 1 R)$, insulin-like growth factor-binding protein 3 and 5 (IGFBP 3 and $I G F B P 5), B A X$, and BCL2 genes on the proliferation and apoptotic rates of mammary epithelial cells, and on milk yield in Saanen goats. In the present study, 3 experiments were conducted: (1) comparing the in vivo effects of first milking, vaccination, vermifugation, preventive hoof trimming, and the administration of $\mathrm{ACTH}$ or a placebo on cortisol release in dairy goats; (2) studying the in vivo effects of immediate increases in cortisol on the mammary gland of lactating goats; and (3) studying the in vitro effects of a prolonged increase in cortisol on mammary epithelial cells obtained from lactating goats. Cortisol release by goats increased significantly after ACTH administration compared with that observed after a placebo, and the cortisol profiles after first milking, vaccination, vermifugation, hoof trimming, and ACTH administration were similar. However, there was no effect of the immediate increase in cortisol in vivo on IGF-1 release, milk yield, milk quality, or the apoptosis and proliferation rates, nor was there any effect on the expression of the target genes. Furthermore, no interaction was observed between IGF-1 and cortisol in either the in vivo or in vitro experiments. However, the addition of cortisol in vitro
\end{abstract}

Received November 10, 2017.

Accepted March 15, 2018

${ }^{1}$ Corresponding author: jnegrao@usp.br significantly increased the expression of the $G H R$ and $I G F 1 R$ genes, which stimulate cell proliferation, and the $B A X$ gene, which causes apoptosis. These contrasting results can explain why cortisol did not change the rates of proliferation or apoptosis in epithelial cells. Indeed, cortisol supplementation in vitro did not change the number or apoptotic rate of epithelial cells over the course of 5 d. Finally, further studies must be performed to understand the effect of cortisol on the expression of the GHR, IGF1R, and BAX genes by epithelial cells and the roles of these genes in milk synthesis during early lactation.

Key words: milk yield, mammary gland, cortisol, cell apoptosis

\section{INTRODUCTION}

Cortisol is essential for copious milk synthesis (Neville et al., 2002; Casey and Plaut, 2007). However, an increase in hypothalamic-pituitary-adrenocortical activity is a characteristic of the stress response (Mormede et al., 2007; Negrao, 2008; Brown and Vosloo, 2017). Furthermore, exogenous glucocorticoids and ACTH administration decrease the plasma concentration of IGF-1 and milk yield in cows (Maciel et al., 2001; Ollier et al., 2016; Ponchon et al., 2017). In fact, administration of a large amount of glucocorticoid over a long period disrupts the growth hormone $(\mathbf{G H}) / \mathrm{IGF}-1$ axis, resulting in inhibition of the action of GH and IGF-I (Lembessis et al., 2004; David et al., 2011; Feng et al., 2013). Indeed, GH and IGF-1, IGFBP-3, and IGFBP-5 also influence the expression of BCL2 (anti-apoptotic) and $B A X$ (pro-apoptotic) genes and have important roles in the regulation of epithelial cell survival (PlathGabler et al., 2001; Sakamoto et al., 2007; Flint et al., 2008). Therefore, the effect of cortisol on milk yield and its influence on the survival of mammary epithelial cells have not been fully elucidated.

At the same time, farm management practices such as vaccination, vermifugation, first milking, weaning, hoof trimming, and transport may cause acute stress, 
cortisol release, and decreased milk yield (Sevi et al., 2001a,b; Canaes et al., 2009; Caroprese et al., 2010). Usually, stress is negatively associated with milk yield, but it is important to understand the relationship between cortisol release and milk yield, because cortisol is necessary to maintain homeostasis and promote animal adaptation (Negrao and Marnet, 2003; Trevisi and Bertoni, 2009; Brown and Vosloo, 2017). In this context, stress and cortisol release are associated with the expression of proteins that regulate cell survival, including BCL2, which prevents apoptosis, and BAX, which initiates the cascade that promotes apoptosis in mammary epithelial cells (Green and Streuli, 2004; Portt et al., 2011; Tao et al., 2015). These contrasting findings concerning the physiological responses related to lactation and stress show that the effects of cortisol on milk synthesis and the survival of epithelial cells remain controversial.

Although exogenous ACTH and glucocorticoid administration has been shown to decrease milk yield in cows (van der Kolk, 1990; Ollier et al., 2016; Ponchon et al., 2017) and ewes (Caroprese et al., 2010), and increase the SCC in milk in dairy ewes (Sevi et al., 2001a,b; Caroprese et al., 2010), the effects of ACTH and glucocorticoid administration on milk yield in goats remains ambiguous. Several authors have reported the absence of a negative effect of administering ACTH and glucocorticoid on the milk yield of dairy goats (Stewart and Thompson, 1984; Anderson et al., 1991; Shamay et al., 2000). In this context, the objective of this study was to evaluate the effect of cortisol on the expression of the IGF1, IGF1R, GHR, IGFBP3, IGFBP5, BAX, and $B C L 2$ genes, the rates of proliferation and apoptosis of mammary epithelial cells, milk quality, and milk yield in Saanen goats.

\section{MATERIALS AND METHODS}

All the animal procedures complied with the ethical code of the Faculty of Animal Science and Food Engineering of the University of São Paulo, Faculty of Animal Science and Food Engineering (FZEA) of the University of São Paulo (USP). The experiment was carried out at the Laboratory of Animal Physiology of the Basic Sciences Department in the Faculty of Animal Science and Food Engineering (FZEA/USP) in Pirassununga, Brazil (at latitude $21^{\circ} 57^{\prime} 02^{\prime \prime} \mathrm{S}$, longitude $47^{\circ}$ $27^{\prime} 50^{\prime \prime} \mathrm{W}$ ). The climate in this area is subtropical, with an average annual temperature of $23^{\circ} \mathrm{C}$ and humidity of $73 \%$, and a rainy season from November to March (with annual rainfall varying from 1,300 to 2,000 $\mathrm{mm}$ ), and the experimental collections were carried out between June and September.

\section{Housing, Diets, and Milking Routine}

All experimental goats were distributed into covered, collective pens with feeding troughs, mineral salt, and water. The feed contained $60 \%$ concentrate and $40 \%$ roughage, providing $100 \%$ of the animals' requirements (NRC, 2007). Milking was conducted twice daily by the same team throughout the experimental period. The milking machine was regulated to maintain a vacuum level of $48 \mathrm{kPa}$ and a pulse rate of 120 cycles/min. The milking routine was performed in accordance with the following protocol: before milking, the animals were attached to a milking machine, and their teats were predipped and dried. The teat cups were attached at time 0 and detached at the end of milking. Afterward, their teats were postdipped, the individual milk yield was recorded, and the animal exited the milking parlor.

\section{Organization of Experiments}

In the present study, 3 experiments were conducted: (1) comparing in vivo the effects of milking, vaccination, vermifugation, hoof trimming, and the administration of ACTH or a placebo on cortisol release in dairy goats; (2) studying in vivo the effects of immediate increases in cortisol on the mammary gland of dairy goats; and (3) studying in vitro the effects of a prolonged increase in cortisol levels on the epithelial cells of dairy goats.

\section{Experiment 1 (Acute Stress and ACTH Administration)}

Twenty-four healthy, homogeneous Saanen goats (mean $\pm \mathrm{SD}$; BW of $55.6 \pm 1.3 \mathrm{~kg}$, BCS of $3.5 \pm$ 1.0, lactating and not pregnant) were used to conduct this experiment. Experimental goats were randomly distributed according to the previous number of parturitions, milk yield, BW, and BCS. These 24 goats were subjected to 6 treatments: first milking, vaccination, vermifugation, preventive hoof trimming, and placebo (saline solution) or ACTH administration. The ACTH dose tested (0.6 UI of $\mathrm{ACTH} / \mathrm{kg}$ of $\mathrm{BW}$ per animal) was based on previous studies that demonstrated that cortisol returned to basal levels just $6 \mathrm{~h}$ after $\mathrm{ACTH}$ administration (Fulkerson and Jamieson, 1982; Alam et al., 1986; Schwinn et al., 2016). This cortisol profile was considered similar to other acute stressors related to farm management (Fulkerson and Jamieson, 1982; Negrao et al., 2004; Negrao, 2008).

At $0800 \mathrm{~h}$ on the experimental day, 4 goats were subjected to first milking, 4 goats were subjected to vaccination, 4 goats were subjected to vermifugation, 4 goats were subjected to preventive hoof trimming, 
4 goats were injected with $\mathrm{ACTH}$, and 4 goats were injected with the placebo. The experimental goats were maintained and brought to the equipment in groups with 6 other goats that did not participate in the experiment. Each procedure was performed with the appropriate equipment, and during the procedures, the goats were immobilized in individual tiestalls. Goats had visual, vocal, and limited tactile contact with neighboring goats during all procedures. The experimental procedures were performed by a trained team, and the time spent to milk each goat was $3 \pm 0.5 \mathrm{~min}$, to vaccinate was $2 \pm 0.2 \mathrm{~min}$, to vermifugate was $1.5 \pm$ $0.2 \mathrm{~min}$, and to trim hooves was $10 \pm 3.1 \mathrm{~min}$. Afterward, the experimental goats were maintained with the other 6 goats that did not participate in the experiment in a collective pen directly after blood sampling.

Blood samples were collected by a puncture from the jugular vein at $30 \mathrm{~min}$ (30 min before), 0 min (just before) and 60, 120, 360, and 1,440 min after first milking, vaccination, vermifugation, hoof trimming, and either ACTH or placebo administration. Blood samples were centrifuged at $1,500 \times g$ and $4^{\circ} \mathrm{C}$ for $17 \mathrm{~min}$, and the plasma was stored at $-20^{\circ} \mathrm{C}$ until cortisol was analyzed. Cortisol was measured by immunoassay analysis using a kit (Monobind, Lake Forest, CA) according to the manufacturer's instructions. In the present study, the cortisol intra- and interassay coefficients of variation were 2.8 and $5.5 \%$, respectively.

\section{Experiment 2 (Effect of Immediate Increase in Cortisol In Vivo)}

An additional herd of 30 homogeneous experimental Saanen goats (BW of $57.5 \pm 1.5 \mathrm{~kg}$, body score of $3.5 \pm$ 1.0, lactating and not pregnant) were used to conduct this experiment. The goats were randomly distributed according to the previous number of parturitions, milk yield, BW, and BCS and subjected to 2 treatments: ACTH and a placebo. On d 30 and 60 of lactation, 15 animals from each group were subjected to the following treatments: (1) ACTH challenge (administration of $0.6 \mathrm{UI} / \mathrm{kg}$ of BW per animal) and (2) placebo (saline solution). This in vivo experiment was performed to study the effect of the immediate increase in cortisol on the mammary gland.

Individual milk yield $(\mathrm{kg})$ was recorded daily. Milk samples were taken weekly from each of the teats of the experimental goats to analyze the milk composition (fat, protein, and lactose) and milk quality (SCC and microbiological analyses). On d 30 and 60 of lactation, milk samples were taken at baseline $(0 \mathrm{~h}$, just before treatment), 12 (evening milking), 24, 36, and $48 \mathrm{~h}$ after
ACTH or placebo administration. The percentage of fat, protein, and lactose was determined by infrared equipment. The SCC was determined by direct microscopy (using Carnoy solution and pyronin Y-methyl green). Microbiological analyses were performed on the milk. After serial dilutions of the milk, each sample was plated and tested on 3 media, standard plate count agar, Baird Parker agar, and MacConkey agar, to count total colony formation. The results were expressed as colony-forming units per milliliter of Enterobacteriaceae and Staphylococcus sp.

On d 30 and 60 of lactation, blood samples were collected from the jugular vein at $-30 \mathrm{~min}$ (30 min before), 0 min (just before) and 60, 120, and $360 \mathrm{~min}$ after ACTH or placebo administration. Blood samples were centrifuged at $1,500 \times g$ and $4^{\circ} \mathrm{C}$ for $17 \mathrm{~min}$, and the plasma was stored at $-20^{\circ} \mathrm{C}$ until the cortisol and IGF-1 analyses were performed. Cortisol was analyzed as described for experiment 1, and IGF-1 was measured by immunoassay analysis using a kit (Enzo, Farmingdale, NY) according to the manufacturer's instructions. In this study, the IGF-1 intra- and interassay coefficients of variation were 4.2 and $6.0 \%$, respectively.

On d 60 of lactation, biopsies of the mammary glands of 8 goats were also performed after challenge with ACTH or the placebo. The 8 goats were randomly distributed, with 4 in each treatment. Each biopsy was performed 30 min after the administration of ACTH or the placebo. After trichotomy, antisepsis, and anesthetic procedures, the skin incision was performed at the medial part of the gland with a scalpel. The disposable biopsy needle was inserted into the incision to a depth of approximately $3.0 \mathrm{~cm}$, and the equipment was triggered to cut and collect a sample of approximately $2.0 \times 0.5 \mathrm{~cm}$ of mammary tissue. Three tissue samples were collected. The first was collected to use in determining the rates of apoptosis and proliferation, the second was used for the analysis of gene expression by reverse-transcription (RT) PCR, and the third was used for cell cultures and the subsequent administration of in vitro treatments.

The rate of apoptosis of the epithelial cells was determined using a terminal deoxynucleotidyl transferase (TdT)-mediated dUTP-biotin nick end labeling (TUNEL) kit according to the manufacturer's instructions (Roche, Indianapolis, IN). Apoptotic cells were counted on slides when their nuclei were intense green. The rate of proliferation of epithelial cells was determined using a proliferating cell nuclear antigen (PCNA) kit according to the manufacturer's instructions (Invitrogen, Burlington, ON, Canada), and proliferating cells were counted on slides when their nuclei 
Table 1. Primer sequences for the genes studied

\begin{tabular}{|c|c|c|c|c|}
\hline Gene $^{1}$ & Sequence & & $\begin{array}{l}\text { GenBank } \\
\text { accession }\end{array}$ & Amplicon (bp) \\
\hline$G A P D H$ & Forward & 5'-GGTGATGCTGGTGCTGAG-3' & AJ431207 & 181 \\
\hline$I G F 1 R$ & $\begin{array}{l}\text { Forward } \\
\text { Reverse }\end{array}$ & $\begin{array}{l}5^{\prime} \text {-TTAAAATGGCCAGAACCTGAG-3' } \\
5^{\prime} \text {-ATTATAACCAAGCCTCCCAC-3' }\end{array}$ & XM_005694951 & 314 \\
\hline IGFBP3 & $\begin{array}{l}\text { Forward } \\
\text { Reverse }\end{array}$ & $\begin{array}{l}\text { 5'-AAAGGTCATGCCAAGGACAG-3' } \\
5^{\prime} \text {-TGCCCGTACTTATCCACACA-3' }\end{array}$ & JQ341161 & 281 \\
\hline$I G F B P 5$ & $\begin{array}{l}\text { Forward } \\
\text { Reverse }\end{array}$ & $\begin{array}{l}5^{\prime} \text {-TGCGAGCTGGTCAAGGAG-3' } \\
5^{\prime} \text {-TCCTCTGCCATCTCGGAG-3' }\end{array}$ & JF720883 & 257 \\
\hline$B C L 2$ & $\begin{array}{l}\text { Forward } \\
\text { Reverse }\end{array}$ & $\begin{array}{l}\text { 5'-GATGACCGAGTATCTGAACCG-3' } \\
5^{\prime} \text {-GACAGCCAGGAGAAATCAAACA-3' }\end{array}$ & NM_001166486 & 120 \\
\hline$B A X$ & $\begin{array}{l}\text { Forward } \\
\text { Reverse }\end{array}$ & $\begin{array}{l}5^{\prime}-\text { TCGGTCTCAACGGCTACA-3' } \\
5^{\prime} \text {-CCACTCCAGCCACAAAGA-3' }\end{array}$ & NM_173894 & 189 \\
\hline
\end{tabular}

${ }^{1}$ Genes were glyceraldehyde 3-phosphate dehydrogenase $(G A P D H)$, growth hormone receptor $(G H R)$, insulin-like growth factor type 1 (IGF1), insulin-like growth factor type 1 receptor $(I G F 1 R)$, insulin-like growth factor-binding proteins 3 and 5 (IGFBP3 and IGFBP5), BAX, and BCL2.

were dark brown. The percentages of proliferating and apoptotic cells were determined by observing 1,000 cells in randomly selected fields.

Gene expression of mammary tissue was performed by extracting RNA with a PureLink RNA Mini Kit (Life Technologies, Carlsbad, CA), and subsequent cDNA synthesis was conducted by RT, where the total RNA $(1.0 \mu \mathrm{g})$ was reverse-transcribed in a final volume of $20 \mu \mathrm{L}$ employing the Improm II kit (Promega, Madison, WI). In summary, the protocol began with the incubation of RNA with $0.5 \mu \mathrm{g}$ oligo-dT for $5 \mathrm{~min}$ at $70^{\circ} \mathrm{C}$. Then, $1 \times$ buffer, $3.0 \mathrm{~m} M \mathrm{MgCl}_{2}, 0.5 \mathrm{~m} M \mathrm{dNTP}$, 40 units of RNase inhibitor, and $1.0 \mu \mathrm{L}$ of Improm reverse transcriptase were added to the reaction tube. The reaction was conducted at $42^{\circ} \mathrm{C}$ for $60 \mathrm{~min}$, followed by $15 \mathrm{~min}$ cooling at 70 and $4^{\circ} \mathrm{C}$. Then, the samples were subjected to RT and subsequent analysis of the amplified gene fragments. The expression of the target genes was determined by RT-PCR using the primers described in Table 1.

Each gene studied was amplified in a separate reaction, and each reaction was performed in duplicate. Each $20 \mu \mathrm{L}$ reaction contained $1.0 \mu \mathrm{L}$ of cDNA sample, $0.4 \mu \mathrm{L}$ of a mixture of a forward primer and reverse primer, $0.4 \mu \mathrm{L}$ of the analyzed genes $[G A P D H$ (housekeeper), GHR, IGF1, IGF1R, IGFBP3, IGFBP 5, BAX, and $B C L 2$ ], $8.2 \mu \mathrm{L}$ of RNA-free water, and $10.0 \mu \mathrm{L}$ of SYBR Green Mix (Invitrogen, Burlington, ON, Canada). The expression of the target genes was normalized to that of GAPDH as calculated by the $2^{-\triangle \Delta \mathrm{CT}}$ method (Schmittgen and Livak, 2008). The samples were then subjected to RT-PCR and subsequent analysis of the amplified gene fragments.

\section{Experiment 3 (Effect of Prolonged Increase in Cortisol In Vitro)}

This in vitro experiment was performed with the goats from experiment 2 to study the effect of a prolonged increase in cortisol on epithelial cells. Compared with experiment 2 in vivo, the experiment 3 studied the effect of large amount of cortisol $(0,10,100$, and $1,000 \mu \mathrm{g} / \mathrm{mL}$ ) for $5 \mathrm{~d}$ in vitro to observe the epithelial cell survival in extreme situations, without affecting other mechanisms, tissues, or glands involved in response to cortisol. The concentrations of cortisol tested were based on previous studies that used between 1 and $10 \mu \mathrm{g} / \mathrm{mL}$ of cortisol to establish epithelial cells culture in vitro (Keys et al., 1997; Pantschenko et al., 2000; Yang et al., 2005), and on our previous in vitro research (data not published) using $0,0.1,1,10$, and $100 \mu \mathrm{g} / \mathrm{mL}$ of cortisol. On d 60 of lactation, samples of the mammary glands of 8 goats (4 goats subjected to $\mathrm{ACTH}$ and another 4 goats subjected to the placebo) were used to establish primary cultures. Individually, the primary cultures of the mammary tissue of the 8 goats were established in a basal medium of Dulbecco's Modified Eagle Medium Nutrient Mixture F-12 Han (DMEM/F12, Gibco Life Technologies, Grand Island, NY) with $10 \%$ fetal bovine serum (Gibco Life Technologies), $100 \mathrm{U} / \mathrm{mL}$ of penicillin, $100 \mu \mathrm{g} / \mathrm{mL}$ of streptomycin, and $2.5 \mu \mathrm{g} / \mathrm{mL}$ of amphotericin B and were incubated at $37^{\circ} \mathrm{C}$ with $5 \% \mathrm{CO}_{2}$ until the cells filled the same plate background. The mammary cells from each experimental goat were counted using automated cell counting equipment (Invitrogen, Waltham, MA) to ensure that all experimental cultures had a minimum 
of $10 \times 10^{4}$ live cells at the beginning of the 8 in vitro treatments. Afterward, mammary epithelial cells from each of the 8 goats were subjected individually to 8 hormone treatments in vitro $(0,10,100$, or $1,000 \mu \mathrm{g} /$ $\mathrm{mL}$ of cortisol together with either 0 or $100 \mathrm{ng} / \mathrm{mL}$ of IGF-1) in triplicate. Eight wells of each treatment studied were harvested for RNA after $5 \mathrm{~d}$ in culture.

For the in vitro treatments, mammary epithelial cells were placed on an individual plate containing a basement membrane matrix $\left(25 \mu \mathrm{L} / \mathrm{cm}^{2}\right.$, BD Biosciences, San Jose, CA) with basal medium (as described above) supplemented with $5 \mu \mathrm{g} / \mathrm{mL}$ of insulin (Sigma Chemical Co., St. Louis, MO), $1 \mu \mathrm{g} / \mathrm{mL}$ of prolactin (Sigma Chemical Co.), and one of the 8 in vitro hormone treatments. This experimental medium was changed at 48 $\mathrm{h}$, and the epithelial cells were incubated for $5 \mathrm{~d}$ to analyze the expression of the GAPDH, GHR, IGF1, $I G F 1 R, I G F B P 3, I G F B P 5, B A X$, and BCL2 genes as described for the in vivo experiment.

\section{Statistical Analysis}

The data were analyzed using Statistical Analysis System software (ver. 9.2, SAS Institute Inc., Cary, NC) after checking their normality according to the residual of the Shapiro-WilkPROC single variable. Cortisol release was subjected to the ANOVA by the mixed procedure in the SAS software, which separated the treatment (first milking, vaccination, vermifugation, hoof trimming, and placebo or ACTH administration), time of sampling and animal as causes of variation. In the model, the treatment effect was considered fixed, and the effects of sampling time and animal were con-

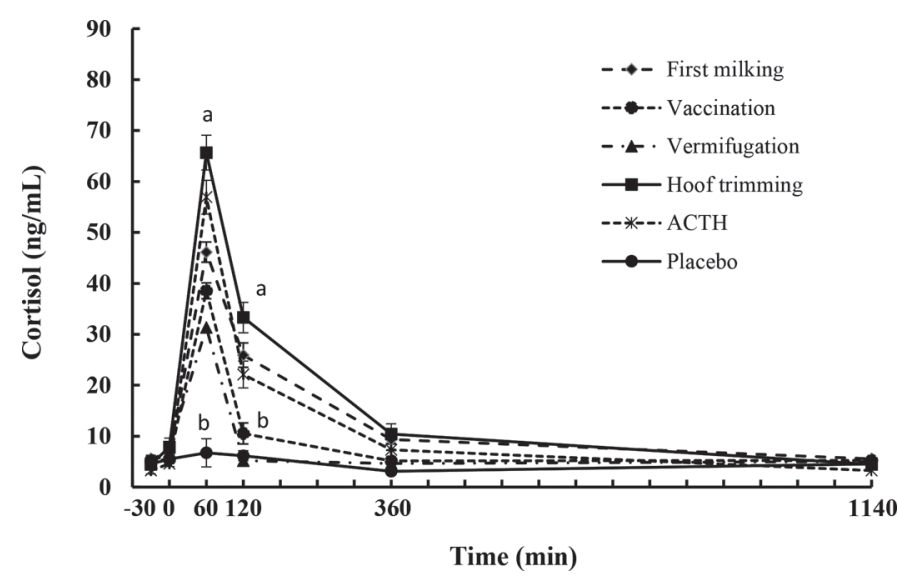

Figure 1. Cortisol $(\mathrm{ng} / \mathrm{mL})$ release in Saanen goats before, during, and after first milking, vaccination, vermifugation, hoof trimming, and ACTH or placebo administration $(\mathrm{n}=4)$. Data are presented as the mean \pm SEM. Means with different letters exhibit statistically significant differences $(P \leq 0.05)$. sidered to be random. Hormone release, milk yield, milk composition and quality were subjected to an ANOVA by the mixed procedure in the SAS software, which separated the treatment (ACTH or placebo), day, sampling time and animal as causes of variation. In the model, the treatment effect was considered fixed, and the effects of the day, sampling time and animal were considered random. Gene expression in vivo and in vitro were subjected to an ANOVA using the general linear model procedure in the SAS software, which separated the treatments $(0,10,100$, or $1,000 \mu \mathrm{g} / \mathrm{mL}$ of cortisol together with 0 or $100 \mathrm{ng} / \mathrm{mL}$ of IGF-1) and animal as causes of variation. In the model, the treatment effect was considered fixed, and the effects of the animals were considered random. When there was a significant effect, the means were compared using Fisher's test with the threshold for significance defined as $P \leq 0.05$.

\section{RESULTS}

\section{Experiment 1}

Goats that received the placebo maintained the basal concentration of cortisol during all experimental sampling. However, there were significant effects of first milking, vaccination, vermifugation, hoof trimming, and ACTH administration on cortisol release when compared with cortisol release in the placebo treatment (Figure 1). The maximum concentration of cortisol was observed 60 min after first milking, vaccination, vermifugation, hoof trimming, and ACTH administration, and the cortisol level remained significantly higher 120 min after first milking, hoof trimming and ACTH treatments than that following the placebo treatment. However, cortisol returned to the basal concentration 360 min after first milking, vaccination, vermifugation, hoof trimming, and ACTH administration. Twentyfour hours (1,440 min) after first milking, vaccination, vermifugation, hoof trimming, or ACTH or placebo administration, cortisol remained at the basal concentration. Finally, cortisol profiles after first milking, vaccination, vermifugation, preventive hoof trimming, and ACTH administration were similar, showing that the $\mathrm{ACTH}$ administration tested was adequate to promote an immediate cortisol increase in dairy goats.

\section{Experiment 2}

There was no effect of ACTH or placebo administration in vivo on milk yield. There was no effect of the treatments or any significant interaction between treatment and sampling time on plasma IGF-1, on fat, 
Table 2. Milk yield; protein, fat, and lactose percentages; SCC; and total counts of bacteria, Enterobacteriaceae, and Staphylococcus sp. measured from 1 to $90 \mathrm{~d}$ of lactation in goats subjected to ACTH or placebo treatment $(\mathrm{n}=15)^{1}$

\begin{tabular}{|c|c|c|c|c|}
\hline \multirow[b]{2}{*}{ Item } & \multicolumn{2}{|c|}{ In vivo treatment } & \multirow[b]{2}{*}{ SEM } & \multirow[b]{2}{*}{$P$-value } \\
\hline & $\mathrm{ACTH}$ & Placebo & & \\
\hline Milk yield (kg) & 2.19 & 2.18 & 0.35 & 0.79 \\
\hline Fat $(\%)$ & 3.98 & 3.82 & 0.34 & 0.29 \\
\hline Protein (\%) & 3.17 & 3.19 & 0.01 & 0.37 \\
\hline Lactose $(\%)$ & 4.31 & 4.34 & 0.02 & 0.34 \\
\hline $\mathrm{SCC}^{2}($ cells $/ \mathrm{mL})$ & $1,403.55$ & $1,323.22$ & 185.54 & 0.77 \\
\hline Total count of bacteria ${ }^{2}(\mathrm{cfu} / \mathrm{mL})$ & 16.87 & 19.92 & 5.09 & 0.08 \\
\hline Enterobacteriaceae ${ }^{3}(\mathrm{cfu} / \mathrm{mL})$ & - & - & - & - \\
\hline Staphylococcus sp. ${ }^{2}(\mathrm{cfu} / \mathrm{mL})$ & 17.25 & 24.37 & 6.66 & 0.09 \\
\hline
\end{tabular}

protein, and lactose percentage, SCC, or the number of colony-forming units in the plate count agar, MacConkey agar, and Baird Parker agar media (Table 2). There was a significant interaction between treatment and sampling time with regard to cortisol release, because in samples taken at 60 and $120 \mathrm{~min}$, cortisol concentrations were higher after ACTH administration than those following the placebo treatment. The cortisol concentration returned to baseline levels 360 min after ACTH treatment and achieved similar values to those after the placebo administration (Figure 2). There was no effect of ACTH or placebo administration on the expression of the GHR, IGF1, IGF1R, IGFBP3, $I G F B P 5, B A X$, or $B C L 2$ genes, nor were there any effects of ACTH or placebo treatment on the percentage of cell proliferation (PCNA) and cell apoptosis (TUNEL) in mammary tissue (Table 3 ).

\section{Experiment 3}

There was no interaction between the supplementation of cortisol and IGF-1 treatments in culture on the expression of the GHR, IGF1, IGF1R, IGFBP3, $I G F B P 5, B A X$, or BCL2 genes by epithelial cells, nor was there an effect of IGF-1 treatment on the expression of the same genes (Table 4). However, there was a significant in vitro effect of the cortisol treatment on the expression of the GHR,IGF1R, and $B A X$ genes, without changing the expression of the IGF1,IGFBP3, and IGFPB5 genes. In fact, the highest expression of the GHR, IGF1R, and $B A X$ genes was observed in the treatment with $1,000 \mu \mathrm{g} / \mathrm{mL}$ of cortisol (Table 5).

\section{DISCUSSION}

In the present study, cortisol release after ACTH challenge was similar to that measured after first milk- ing, vaccination, vermifugation and hoof trimming. Furthermore, the cortisol increase was temporary, and the rapid return to the basal concentration was similar to that observed after first milking, vaccination, vermifugation, hoof trimming and ACTH administration. In general, the duration of a stressful event is used to class the stressor as acute or chronic. In this context, cortisol release is fundamental to the study of the response of the hypothalamic-pituitary-adrenal (HPA) axis to both types of stressors. Acute stress is established when a stressor occurs over few minutes or hours, and cortisol concentration returns to baseline between 4 and $6 \mathrm{~h}$ after to its basal concentration and homeostasis (Mormede et al., 2007; Trevisi and Bertoni, 2009; Chen et al., 2015). As in other studies (Verkerk et al., 1994; Jensen et al., 1996; Negrao and Marnet, 2003; Larzul et al., 2015), in the present study, ACTH administration caused a cortisol release similar to other acute stressors related to other farm management practices performed during goat lactation. Therefore, the ACTH dose used was considered adequate to study the immediate effect of cortisol on the mammary gland of dairy goats.

In contrast, chronic stress is established when a continuous or cumulative stressor is maintained. In that case, the cortisol concentration remains significantly higher than the basal concentration (Mormede et al., 2007; Kassahn et al., 2009; Brown and Vosloo, 2017), causing cumulative and negative effects for animals. In general, large amounts of exogenous glucocorticoids reduce milk yield (van der Kolk, 1990; Ollier et al., 2016; Ponchon et al., 2017). Indeed, other studies have shown that glucocorticoid administration was also associated with decreases in the immune response and failure of the HPA axis (Kassahn et al., 2009; Caroprese et al., 2010; Larzul et al., 2015). However, in the present study, no effect was observed of ACTH administration and cortisol increase on IGF-1 release in plasma, milk yield, 


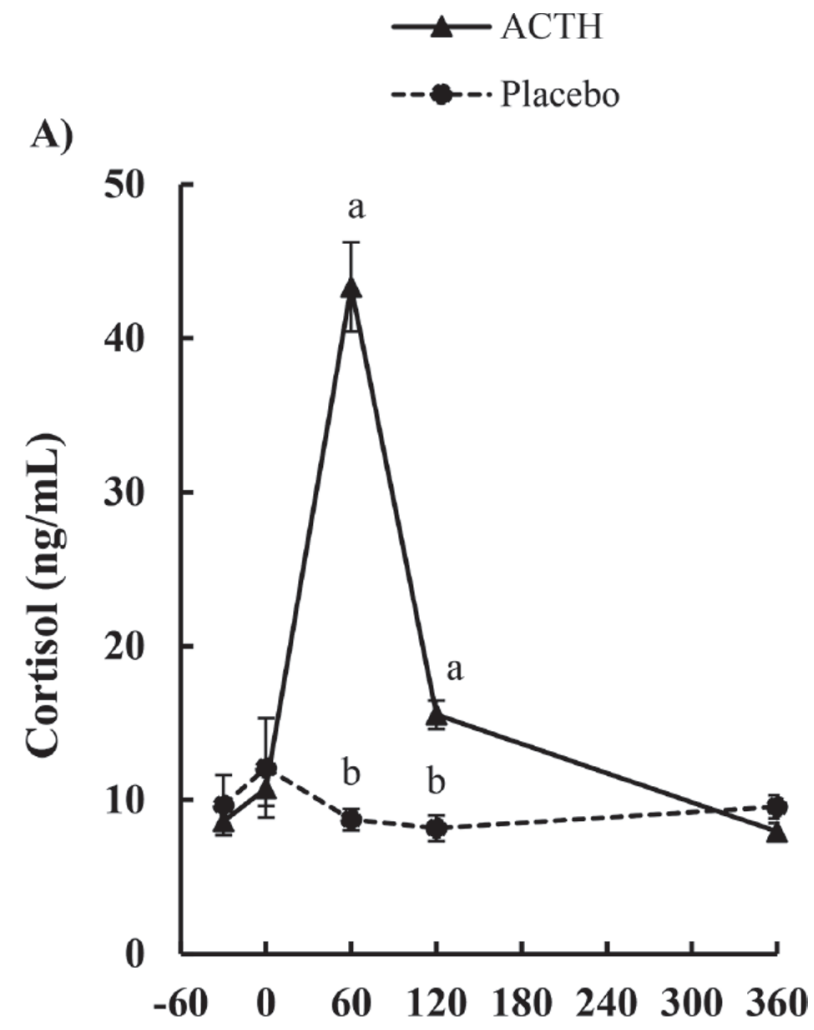

B)

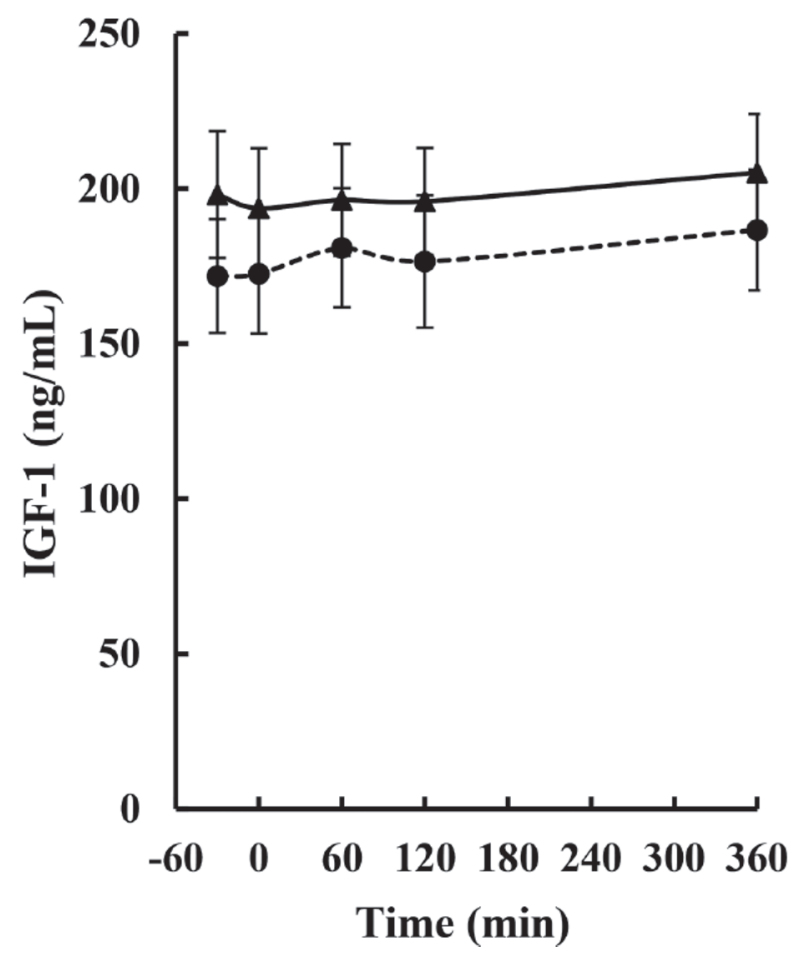

Figure 2. Cortisol $(\mathrm{ng} / \mathrm{mL})$ and IGF-1 $(\mathrm{ng} / \mathrm{mL})$ released in Saanen goats on d 60 of lactation before, during, and after ACTH or placebo administration $4(\mathrm{n}=15)$. Data are presented as the mean \pm SEM. Means with different letters exhibit statistically significant differences $(P \leq 0.05)$. or milk quality. Similarly, other studies that also used ACTH or glucocorticoid administration did not observe any negative effect on either milk quality or milk yield in dairy goats (Stewart and Thompson, 1984; Anderson et al., 1991; Shamay et al., 2000). For these reasons, we proposed to study the effect of high levels of cortisol in mammary tissue in vitro to verify the possible local effect of cortisol without affecting other mechanisms, tissues or glands involved in complex responses to stress.

In fact, the majority of studies that used large amounts of glucocorticoids or ACTH by a single or repeated administration observed a significant decrease in IGF-1 release and milk yield in cows (van der Kolk, 1990; Ollier et al., 2016; Ponchon et al., 2017) and ewes (Caroprese et al., 2010). Furthermore, previous studies with lactating ewes also reported that higher cortisol release due to stress decreased milk yield and increased SCC (Sevi et al., 2001a,b; Caroprese et al., 2010). However, in the present study, the ACTH challenge did not change the SCC or total counts of Enterocobacteriaceae and Staphylococcus sp. in milk compared with those in control goats. Indeed, the SCC and bacteria counts in the milk following both ACTH and placebo treatments were similar to those in control goats (Paape et al., 2001, 2007; Barron-Bravo et al., 2013). These results confirmed that the immediate increase in cortisol after ACTH administration did not influence milk yield, milk quality or the susceptibility of experimental goats to microorganisms that may cause mastitis.

At the same time, no effect was observed of ACTH administration on IGF-1 release in plasma, or on the expression of the IGF1,IGF1R, GHR, IGFBP3, $I G F B P 5, B A X$, and $B C L 2$ genes in the mammary tissue of the experimental goats. Thus, there was no in vivo effect of the immediate increase in cortisol on proliferation and apoptosis rates in mammary tissue, nor was there any effect on milk yield measured before or after both treatments. Consequently, it is possible to argue that the ACTH dose used in the present study was not sufficiently high to have a negative effect on the mammary gland. However, as discussed above, the $\mathrm{ACTH}$ dose tested caused an increase in cortisol release similar to that observed during first milking, vaccination, vermifugation and preventive hoof trimming. Furthermore, the cortisol concentration measured after ACTH treatment was similar to that observed by other authors who reported a decrease in milk yield when working with other stressors (Sevi et al., 2001a,b; Negrao and Marnet, 2003; Canaes et al., 2009; Caroprese et al., 2010).

In this context, it is possible to argue that the negative effect of the increase in cortisol on mammary glands following an acute stressor is overestimated for healthy animals during early lactation, because HPA responses, 
Table 3. Relative expression of target genes and the percentages of cell proliferation and cell apoptosis in fresh mammary tissue of goats subjected to ACTH or placebo treatment $(\mathrm{n}=15)^{1}$

\begin{tabular}{lcccc}
\hline & \multicolumn{2}{c}{ In vivo treatment } & & \\
\cline { 2 - 3 } Item $^{2}$ & ACTH & Placebo & SEM & $P$-value \\
\hline$G H R$ & 1.42 & 1.21 & 0.16 & 0.14 \\
$I G F 1$ & 1.44 & 1.40 & 0.31 & 0.94 \\
$I G F 1 R$ & 1.17 & 1.48 & 0.26 & 0.46 \\
$I G F B P 3$ & 0.85 & 1.09 & 0.13 & 0.28 \\
$I G F B P 5$ & 2.44 & 1.69 & 0.88 & 0.62 \\
BAX & 1.20 & 1.48 & 0.29 & 0.51 \\
BCL2 & 1.70 & 2.39 & 0.67 & 0.55 \\
Cell proliferation (\%) & 20.15 & 22.04 & 1.58 & 0.63 \\
Cell apoptosis (\%) & 10.26 & 11.21 & 1.81 & 0.78 \\
\hline${ }^{1}$ Mammary biopsies were obtained at $60 \mathrm{~d}$ of lactation. Data are presented as the mean \pm SEM. \\
${ }^{2}$ Genes were growth hormone receptor (GHR), insulin-like growth factor type 1 (IGF1), insulin-like growth \\
factor type 1 receptor $(I G F 1 R)$, insulin-like growth factor binding proteins 3 and 5 (IGFBP3 and IGFBP5), \\
BAX, and BCL2.
\end{tabular}

mainly cortisol release, are considered necessary for the return of that animal to homeostasis (Mormede et al., 2007; Brown and Vosloo, 2017). Although improvements in farm management practices are necessary to promote animal production and welfare (Chen et al., 2015; Brown and Vosloo, 2017), physiological responses to acute stressors promote animal adaptation. However, in the in vitro study, there was also no effect of IGF-1 treatment, nor was there any interaction between IGF-1 and cortisol treatment on the expression of the IGF1,IGF1R, GHR, IGFBP3, IGFBP5, BAX, and $B C L 2$ genes by mammary cells in vitro. Taking into account these results, we cannot speculate about the negative effect of cortisol on the action of IGF-1, nor can we speculate about the positive effect of IGF-1 on cell proliferation and the survival of epithelial cells in vitro. In fact, our initial argument that IGF-1 plays

Table 4. Relative expression of target genes by goat primary mammary epithelial cells cultured with 0 and $100 \mathrm{ng} / \mathrm{mL}$ of IGF-1 $(\mathrm{n}=8)^{1}$

\begin{tabular}{|c|c|c|c|c|}
\hline \multirow[b]{2}{*}{ Item $^{2}$} & \multicolumn{2}{|c|}{$\begin{array}{c}\text { In vitro IGF-1 treatment } \\
(\mathrm{ng} / \mathrm{mL})\end{array}$} & \multirow[b]{2}{*}{ SEM } & \multirow[b]{2}{*}{$P$-value } \\
\hline & 0 & 100 & & \\
\hline$G H R$ & 1.32 & 1.14 & 0.23 & 0.15 \\
\hline$I G F 1$ & 0.20 & 0.13 & 0.06 & 0.21 \\
\hline$I G F 1 R$ & 1.53 & 1.54 & 0.18 & 0.84 \\
\hline IGFBP & 1.48 & 1.13 & 0.20 & 0.33 \\
\hline IGFBP5 & 1.41 & 1.37 & 0.34 & 0.96 \\
\hline$B A X$ & 1.52 & 1.38 & 0.16 & 0.23 \\
\hline BCL2 & 1.14 & 1.01 & 0.14 & 0.35 \\
\hline
\end{tabular}

${ }^{1}$ Mammary biopsies were obtained at $60 \mathrm{~d}$ of lactation. Data are presented as the mean \pm SEM.

${ }^{2}$ Genes were growth hormone receptor $(G H R)$, insulin-like growth factor type 1 (IGF1), insulin-like growth factor type 1 receptor $(I G F 1 R)$, insulin-like growth factor-binding proteins 3 and 5 (IGFBP3 and $I G F B P 5), B A X$, and BCL2. a local role in conjunction with IGF-1R, IGFBP-3 and IGFBP-5 in inhibiting apoptosis and minimizing the action of cortisol on epithelial cells was not confirmed.

In vitro, the addition of cortisol did not change the expression of the IGF1,IGFBP3, or IGFBP 5 genes, or proliferation and apoptosis in the mammary tissue of the experimental goats. The action of IGF-1 on target cells is influenced by its bond to BPs, some studies have shown that the interaction between IGF-1 and IGFBP-3 is related to cell proliferation and that the interaction between IGF-1 and IGFBP-5 is related to cell apoptosis on mammary gland (Sakamoto et al., 2007; Flint et al., 2008; Murney et al., 2015). These different relationships between IGF-1 and IGFBP-3 and -5 can explain the effect of IGF- 1 on both cell proliferation and apoptosis. As in the present study, cortisol supplementation in vitro did not significantly influence the expression of IGF1, IGFBP3, or IGFBP 5 in epithelial cells, and cortisol did not change proliferation or apoptosis rates in epithelial cells. These results in vitro show that our initial hypothesis that cortisol influences apoptosis and proliferation rates through the expression of IGF1,IGFBP3, and IGFBP5 in mammary epithelial cells was not confirmed.

Conversely, in vitro cortisol supplementation significantly increased the expression of GHR and IGF1R in epithelial cells. Other authors have reported that GH and IGF-1 can modulate the survival of epithelial cells (Capuco et al., 2001; Flint et al., 2005; Rosenfeld and Hwa, 2009), and the increase in expression of GHR and IGF1R observed in vitro in the study can explain why GH and IGF-1 were previously associated with cell proliferation (Flint et al., 2008; Murney et al., 2015). As cortisol did not change the expression of IGF1, IGFBP3, or IGFBP5, our results demonstrated the direct effect of cortisol on the expression of $G H R$ 
Table 5. Relative expression of target genes, cell number, and percentage of apoptosis in goat primary mammary epithelial cells cultured with $0,10,100$, and $1,000 \mu \mathrm{g} / \mathrm{mL}$ of cortisol $(\mathrm{n}=8)^{1}$

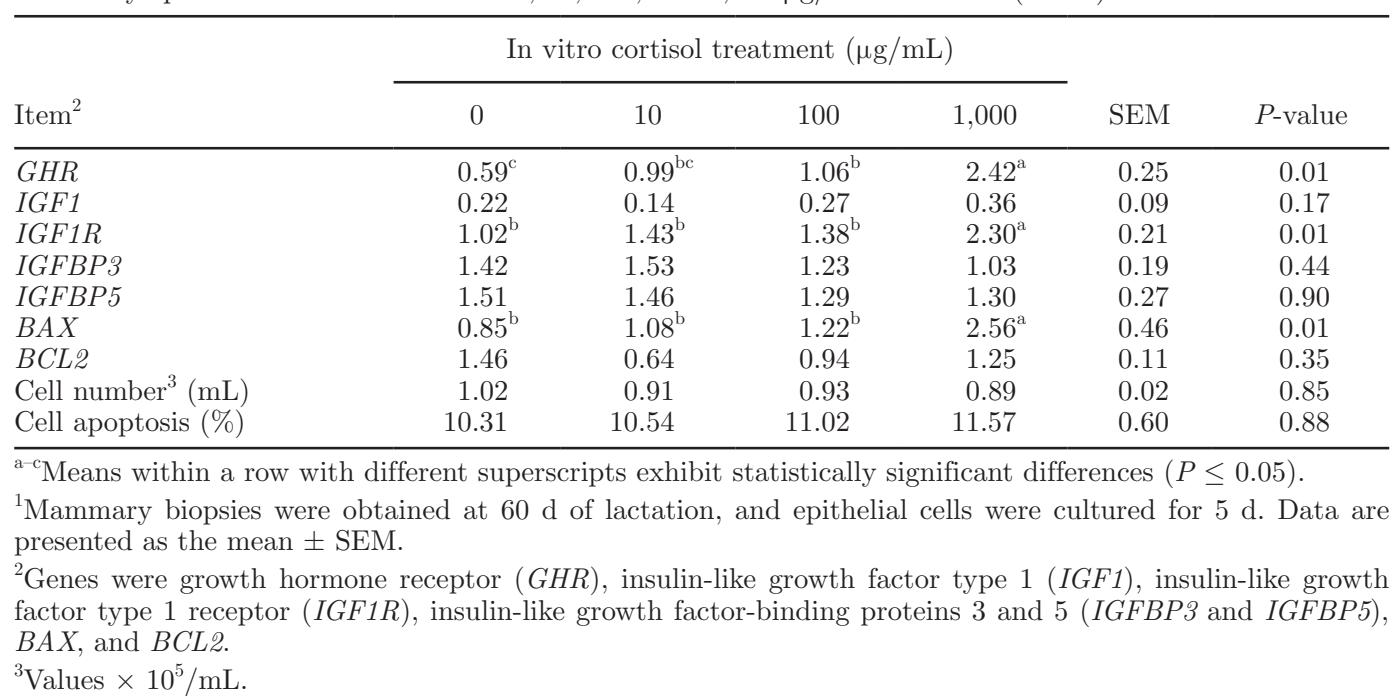

and IGF1R in mammary tissue, further suggesting that large amounts of cortisol can improve the actions of GH and IGF-1 in mammary cells, as reported in other studies that worked with large amounts by long-term exposure to glucocorticoid and other cells (Savage et al., 2011; Vakili and Cattini, 2012). In fact, the overexpression of GHR and IGF1R genes protects different cells against apoptosis (Mueller et al., 2012; Feng et al., 2013; Murney et al., 2015).

In contrast, cortisol supplementation also significantly increased the expression of the $B A X$ gene (proapoptotic) without changing the expression of the $B C L 2$ gene (anti-apoptotic) in epithelial cells in vitro. This imbalance in the expression of $B A X$ and $B C L 2$ can induce the expression of proteins which initiates apoptosis in mammary epithelial cells, because BAX is involved in the cascade of proteins that promote the cleavages that cause cell apoptosis (Valentijn and Gilmore, 2004; Jin and El-Deiry, 2005; Katz and Streuli, 2007). Other authors have suggested that long-term exposure to glucocorticoid can negatively regulate the expression of GH and IGF1 genes in other cell models (Lembessis et al., 2004; Feng et al., 2013). However, in the present study, the cell number and percentage of apoptosis was not changed by cortisol supplementation in vitro, showing that the survival effects promoted by higher expression of GHR and IGF1R genes have overlapping apoptotic effects of higher expression of $B A X$ gene in epithelial cells.

Consequently, in the present study, cortisol supplementation significantly increased the expression of the GHR, IGF1R, and BAX genes by epithelial cells in vitro. These results were unexpected, because cortisol has been shown to have opposing effects on epithelial cells: (1) increasing the expression of GHR and $I G F 1 R$, which stimulates the survival of epithelial cells, and (2) increasing the expression of $B A X$, which induces apoptosis. Taking into account the fact that cortisol supplementation did not change the cell number or apoptotic rate of epithelial cells maintained in culture for $5 \mathrm{~d}$, it is possible to argue that cortisol did not change the survival of epithelial cells, showing that large amounts of cortisol in vitro had no negative effects on mammary glands during early lactation in Saanen goats. However, further studies need to be performed to understand how cortisol can modulate the expression of GHR, IGF1R, and $B A X$ and to elucidate their roles in milk synthesis.

\section{ACKNOWLEDGMENTS}

The authors thank the São Paulo Research Foundation (FAPESP, Brazil, grants 16/00123-3), Conselho Nacional de Desenvolvimento Científico e Tecnológico (Brazil), and Coordenação de Aperfeiçoamento de Pessoal de Nível Superior (Brazil) for financial support and scholarships.

\section{REFERENCES}

Alam, M. G. S., H. Dobson, and R. J. Fitzpatrick. 1986. Endocrine response to different doses of ACTH in cows. Br. Vet. J. 142:239245.

Anderson, K. L., E. Hunt, and B. J. Davis. 1991. The influence of anti-inflammatory therapy on bacterial clearance following intramammary Escherichia coli challenge in goats. Vet. Res. Commun. 15:147-161.

Barron-Bravo, O. G., A. J. Gutierrez-Chavez, C. A. Angel-Sahagun, H. H. Montaldo, L. Shepard, and M. Valencia-Posadas. 2013. 
Losses in milk yield, fat and protein contents according to different levels of somatic cell count in dairy goats. Small Rumin. Res. 113:421-431.

Brown, E. J., and A. Vosloo. 2017. The involvement of the hypothalamopituitary-adrenocortical axis in stress physiology and its significance in the assessment of animal welfare in cattle. Onderstepoort J. Vet. Res. 84:e1-e9.

Canaes, T. S., J. A. Negrao, F. A. Paiva, M. Zaros, and T. F. G. Delgado. 2009. Physiologic and productive responses of Alpine goats submitted to transportation to a new dairy location. Arq. Bras. Med. Vet. Zootec. 61:935-940.

Capuco, A. V., D. L. Wood, R. Baldwin, K. McLeod, and M. J. Paape. 2001. Mammary cell number, proliferation, and apoptosis during a bovine lactation: Relation to milk production and effect of bST. J. Dairy Sci. 84:2177-2187.

Caroprese, M., M. Albenzio, A. Marzano, L. Schena, G. Annicchiarico, and A. Sevi. 2010. Relationship between cortisol response to stress and behavior, immune profile, and production performance of dairy ewes. J. Dairy Sci. 93:2395-2403.

Casey, T. M., and K. Plaut. 2007. The role of glucocorticoids in secretory activation and milk secretion, a historical perspective. J. Mammary Gland Biol. Neoplasia 12:293-304.

Chen, Y., R. Arsenault, S. Napper, and P. Griebel. 2015. Models and methods to investigate acute stress responses in cattle. Animals (Basel) 5:1268-1295.

David, A., V. Hwa, L. A. Metherell, I. Netchine, C. Camacho-Hubner, A. J. L. Clark, R. G. Rosenfeld, and M. O. Savage. 2011. Evidence for a continuum of genetic, phenotypic, and biochemical abnormalities in children with growth hormone insensitivity. Endocr. Rev. 32:472-497.

Feng, Y. Z., M. Famuyide, and A. J. Bhatt. 2013. Dexamethasone decreases insulin-like growth factor-I and -II via a glucocorticoid receptor dependent mechanism in developing rat brain. Neuroendocrinol. Lett. 34:624-634.

Flint, D. J., M. Boutinaud, E. Tonner, C. J. Wilde, W. Hurley, P. A. Accorsi, A. F. Kolb, C. B. A. Whitelaw, J. Beattie, and G. J. Allan. 2005. Insulin-like growth factor binding proteins initiate cell death and extracellular matrix remodeling in the mammary gland. Domest. Anim. Endocrinol. 29:274-282.

Flint, D. J., E. Tonner, J. Beattie, and G. J. Allan. 2008. Role of insulin-like growth factor binding proteins in mammary gland development. J. Mammary Gland Biol. Neoplasia 13:443-453.

Fulkerson, W. J., and P. A. Jamieson. 1982. Pattern of cortisol release in sheep following administration of synthetic ACTH or imposition of various stressor agents. Aust. J. Biol. Sci. 35:215-222.

Green, K. A., and C. H. Streuli. 2004. Apoptosis regulation mammary gland. Cell. Mol. Life Sci. 61:1867-1883.

Jensen, K. H., L. J. Pedersen, E. K. Nielsen, K. E. Heller, J. Ladewig, and E. Jorgensen. 1996. Intermittent stress in pigs: Effects on behavior, pituitary-adrenocortical axis, growth, and gastric ulceration. Physiol. Behav. 59:741-748.

Jin, Z. Y., and W. S. El-Deiry. 2005. Overview of cell death signaling pathways. Cancer Biol. Ther. 4:139-163.

Kassahn, K. S., R. H. Crozier, H. O. Portner, and M. J. Caley. 2009. Animal performance and stress: responses and tolerance limits at different levels of biological organisation. Biol. Rev. Camb. Philos. Soc. 84:277-292.

Katz, E., and C. H. Streuli. 2007. The extracellular matrix as an adhesion checkpoint for mammary epithelial function. Int. J. Biochem. Cell Biol. 39:715-726.

Keys, J. E., J. P. Van Zyl, and H. M. Farrell Jr.. 1997. Effect of somatotropin and insulin-like growth factor-I on milk lipid and protein synthesis in vitro. J. Dairy Sci. 80:37-45.

Larzul, C., E. Terenina, A. Foury, Y. Billon, I. Louveau, E. Merlot, and P. Mormede. 2015. The cortisol response to ACTH in pigs, heritability and influence of corticosteroid-binding globulin. Animal 9:1929-1934.

Lembessis, P., N. Kalariti, and M. Koutsilieris. 2004. Glucocorticoid receptor function suppresses insulin-like growth factor 1 activity in human KLE endometrial-like cells. In Vivo 18:43-47.
Maciel, S. M., C. S. Chamberlain, R. P. Wettemann, and L. J. Spicer. 2001. Dexamethasone influences endocrine and ovarian function in dairy cattle. J. Dairy Sci. 84:1998-2009.

Mormede, P., S. Andanson, B. Auperin, B. Beerda, D. Guemene, J. Malmkvist, X. Manteca, G. Manteuffel, P. Prunet, C. G. van Reenen, S. Richard, and I. Veissier. 2007. Exploration of the hypothalamic-pituitary-adrenal function as a tool to evaluate animal welfare. Physiol. Behav. 92:317-339

Mueller, K. M., M. Themanns, K. Friedbichler, J. W. Kornfeld, H. Esterbauer, J. P. Tuckermann, and R. Moriggl. 2012. Hepatic growth hormone and glucocorticoid receptor signaling in body growth, steatosis and metabolic liver cancer development. Mol. Cell. Endocrinol. 361:1-11.

Murney, R., K. Stelwagen, T. T. Wheeler, J. K. Margerison, and K. Singh. 2015. The effects of milking frequency on insulin-like growth factor I signaling within the mammary gland of dairy cows. J. Dairy Sci. 98:5422-5428.

Negrao, J. A. 2008. Hormone release and behavior during suckling and milking in Gir, Gir x Holstein, and Holstein cows. J. Anim. Sci. $86: 21-26$.

Negrao, J. A., and P. G. Marnet. 2003. Cortisol, adrenalin, noradrenalin and oxytocin release and milk yield during first milkings in primiparous ewes. Small Rumin. Res. 47:69-75.

Negrao, J. A., M. A. F. Porcionato, A. M. de Passillé, and J. Rushen. 2004. Cortisol in saliva and plasma of cattle after ACTH administration and milking. J. Dairy Sci. 87:1713-1718.

Neville, M. C., T. B. McFadden, and I. Forsyth. 2002. Hormonal regulation of mammary differentiation and milk secretion. J. Mammary Gland Biol. Neoplasia 7:49-66.

NRC. 2007. Nutrients Requirements of Small Ruminant: Sheep, Goats, Cervids and New World Camelids. 1st ed. National Academy Press, Washington, DC.

Ollier, S., F. Beaudoin, N. Vanacker, and P. Lacasse. 2016. Effect of reducing milk production using a prolactin-release inhibitor or a glucocorticoid on metabolism and immune functions in cows subjected to acute nutritional stress. J. Dairy Sci. 99:9949-9961.

Paape, M. J., B. Poutrel, A. Contreras, J. C. Marco, and A. V. Cappuco. 2001. Milk somatic cells and lactation in small ruminants. J. Dairy Sci. 84:E237-E244.

Paape, M. J., G. R. Wiggans, D. D. Bannerman, D. L. Thomas, A. H. Sanders, A. Contreras, P. Moroni, and R. H. Miller. 2007. Monitoring goat and sheep milk somatic cell counts. Small Rumin. Res. $68: 114-125$.

Pantschenko, A. G., J. Woodcock-Mitchell, S. L. Bushmich, and T. J. Yang. 2000. Establishment and characterization of a caprine mammary epithelial cell line (CMEC). In Vitro Cell. Dev. Biol. Anim. 36:26-37.

Plath-Gabler, A., C. Gabler, F. Sinowatz, B. Berisha, and D. Schams. 2001. The expression of the IGF family and GH receptor in the bovine mammary gland. J. Endocrinol. 168:39-48.

Ponchon, B., X. Zhao, S. Ollier, and P. Lacasse. 2017. Relationship between glucocorticoids and prolactin during mammary gland stimulation in dairy cows. J. Dairy Sci. 100:1521-1534.

Portt, L., G. Norman, C. Clapp, M. Greenwood, and M. T. Greenwood. 2011. Anti-apoptosis and cell survival: A review. Biochim. Biophys. Acta 1813:238-259.

Rosenfeld, R. G., and V. Hwa. 2009. The growth hormone cascade and its role in mammalian growth. Horm. Res. 71:36-40.

Sakamoto, K., T. Yano, T. Kobayashi, A. Hagino, H. Aso, and Y. Obara. 2007. Growth hormone suppresses the expression of IGFBP-5, and promotes the IGF-I-induced phosphorylation of Akt in bovine mammary epithelial cells. Domest. Anim. Endocrinol. 32:260-272.

Savage, M. O., D. Simon, and P. C. Czernichow. 2011. Growth hormone treatment in children on chronic glucorticoid therapy. Endocr. Dev. 20:194-201.

Schmittgen, T. D., and K. J. Livak. 2008. Analyzing real-time PCR data by the comparative C-T method. Nat. Protoc. 3:1101-1108.

Schwinn, A., C. Knight, R. M. Bruckmaier, and J. J. Gross. 2016. Suitability of saliva cortisol as a biomarker for hypothalamic-pituitary-adrenal axis activation assessment, effect of feeding actions, 
and immunostimulatory challenges in dairy cows. J. Anim. Sci. 94:2357-2365

Sevi, A., G. Annicchiarico, M. Albenzio, L. Taibi, A. Muscio, and S. Dell'Aquila. 2001a. Effects of solar radiation and feeding time on behavior, immune response and production of lactating ewes under high ambient temperature. J. Dairy Sci. 84:629-640.

Sevi, A., L. Taibi, M. Albenzio, A. Muscio, S. Dell'Aquila, and F. Napolitano. 2001b. Behavioral, adrenal, immune, and productive responses of lactating ewes to regrouping and relocation. J. Anim. Sci. 79:1457-1465.

Shamay, A., S. J. Mabjeesh, and F. Shapiro. 2000. Adrenocorticotrophic hormone and dexamethasone failed to affect milk yield in dairy goats: Comparative aspects. Small Rumin. Res. 38:255-259.

Stewart, H. J., and G. E. Thompson. 1984. Adrenocorticotrophic hormone stimulation of mammary secretion in lactating goats independent of increased mammary uptake of glucose. J. Endocrinol. 101:203-211

Tao, S. Y., J. Tian, R. H. Cong, L. L. Sun, Y. Q. Duanmu, H. B. Dong, Y. D. Ni, and R. Q. Zhao. 2015. Activation of cellular apoptosis in the caecal epithelium is associated with increased oxidative reac- tions in lactating goats after feeding a high-concentrate diet. Exp. Physiol. 100:278-287.

Trevisi, E., and G. Bertoni. 2009. Some physiological and biochemical methods for acute and chronic stress evaluation in dairy cows. Ital. J. Anim. Sci. 8:265-286.

Vakili, H., and P. A. Cattini. 2012. The hidden but positive role for glucocorticoids in the regulation of growth hormone-producing cells. Mol. Cell. Endocrinol. 363:1-9.

Valentijn, A. J., and A. P. Gilmore. 2004. Translocation of full-length Bid to mitochondria during anoikis. J. Biol. Chem. 279:3284832857.

van der Kolk, J. H. 1990. The bovine pituitary-adrenocortical axis and milk-yield. Vet. Q. 12:114-120.

Verkerk, G. A., K. L. Macmillan, and L. M. McLeay. 1994. Adrenal cortex response to adrenocorticotropic hormone in dairy cattle. Domest. Anim. Endocrinol. 11:115-123.

Yang, J., B. Zhao, V. E. Baracos, and J. J. Kennelly. 2005. Effects of bovine somatotropin on beta-casein mRNA levels in mammary tissue of lactating cows. J. Dairy Sci. 88:2806-2812. 